\title{
STROKE IN HIV INFECTED PATIENTS. IS IT MORE FREQUENT AND ARE THEY ATTENDED WORSE?
}

\author{
A. de Arce Borda1 ${ }^{1}$, M. Goenaga Sánchez², P. de La Riva Juez¹, F. González López¹ , N. Díez González¹, M.Arruti González¹ , M. Von \\ Wichmann de Miguel ${ }^{2}$, F. Rodriguez Arrondo ${ }^{2}$, X. Camino Ortiz de Barron², M.Bustinduy Odriozola ${ }^{2}$, H. Azkune Galparsoro² , M. \\ Ibarguren Pinilla ${ }^{2}$, X. Kortajarena Urkola² , A. Muñoz Lopetegi ${ }^{1}$, G. Fernández García de Eulate ${ }^{1}$, J. Rodriguez Antigüedad ${ }^{1}$, D. \\ Campo Caballero', J. Iribarren Loyarte ${ }^{2}$, M. Martínez Zabaleta ${ }^{1}$. \\ 1. OSI Donostialdea Hospital Universitario Donostia., Neurología, Donostia, Spain. \\ 2. OSI Donostialdea Hospital Universitario Donostia., Enfermedades infecciosas, Donostia, Spain.
}

Background and objectives: It is believed that HIVinfected patients have a higher risk of stroke and that they receive a different acute phase attention. The aim of this study is to determine if this is true in our environment.

Methods: Retrospective analysis of a series of cases of stroke in a HIV population in Gipuzkoa since 2009. The attention in the emergency room and the reason for not been admitted in the stroke unit (SU) are analized when this occurs

Results: 30 patients were included (mean age 56 years, range $45-80$ ), $80 \%$ male, and an incidence of 3.04 cases per 1000 patient-year. $67 \%$ were ischemic stroke (IS) and $33 \%$ hemorrhagic stroke (HS).

Baseline characteristics:

\begin{tabular}{ll}
\hline Parenteral drug use & $67 \%$ \\
HBP & $46 \%$ \\
Smoke & $63 \%$ \\
Mean CD 4 & 665 cells \\
Undetectable viral load & $83 \%$ \\
\hline
\end{tabular}

\begin{tabular}{l|c|c|c|}
\hline \multicolumn{3}{|c|}{ Epidemiology } & \multicolumn{3}{|c|}{} \\
\hline HIV population & $3.04 c / 1000 p-y$ & 56 & $45-80$ \\
\hline $\begin{array}{l}\text { General } \\
\text { population }\end{array}$ & $1,61 c / 1000 p-y$ & 76 & $6-96$ \\
\hline
\end{tabular}

Admited in the Stroke Unit

\begin{tabular}{|l|l|l|}
\hline ISCHEMIC STROKE & \multicolumn{1}{|c|}{$\begin{array}{c}\text { HEMORRHAGIC } \\
\text { STROKE }\end{array}$} \\
\hline HIV population & $50 \%$ admitted in the SU & $20 \%$ admitted in the SU \\
\hline General population & $49 \%$ admitted in the SU & $35.5 \%$ admitted in the SU \\
\hline
\end{tabular}

Mortality at discharge

\begin{tabular}{|l|r|r|} 
& ISCHEMIC STROKE & \multicolumn{2}{|c|}{$\begin{array}{c}\text { HEMORRHAGIC } \\
\text { STROKE }\end{array}$} \\
\hline HIV population & $25 \%$ & $60 \%$ \\
\hline General population & $9.4 \%$ & $34.4 \%$ \\
\hline
\end{tabular}

Acute phase attention:

No thrombolysis or thrombectomy was performed.

In $22 \%$, no neurological care was requested despite fullfilling criteria for admission to the stroke unit.

The reason for not entering the stroke unit were: $>24 \mathrm{~h}$ from the beginning of symptoms (39\%) and coma or need of orotracheal intubation (28\%).

\section{Conclusions:}

1.- HIV-infected patients have an increased incidence of stroke at younger ages.

2.- In our enviroment, the main reason for not entering stroke units is a delay in the search of care.

3.- It would be advisable to implement health education on early detection of stroke in this population. 